\title{
Partial Nucleotide Sequence of 16S Ribosomal RNA Isolated from Armadillo-grown Mycobacterium leprae
}

\author{
By IRIS C. E. ESTRADA-G., F. IAN LAMB, M. JOSEPH COLSTON AND \\ ROBERT A. COX* \\ National Institute for Medical Research, The Ridgeway, Mill Hill, London NW7 1AA, UK
}

(Received 14 December 1987; revised 22 January 1988)

\begin{abstract}
Ribosomal RNA (rRNA) was isolated from Mycobacterium leprae recovered from infected tissue of the Nine-banded Armadillo, and nucleotide sequences near the $3^{\prime}$ end of the 16S species were determined by primer extension in the presence of dideoxynucleotides. Previously published data for bacterial 16S rRNAs show a pattern of conserved and non-conserved sequences that fit a common secondary structure. Our data for $M$. leprae fit this general pattern.
\end{abstract}

\section{INTRODUCTION}

Little is known about the genome of Mycobacterium leprae because of the difficulties in culturing and manipulating this organism. However, some progress has recently been made in cloning and expressing $M$. leprae DNA (Clark-Curtis et al., 1985; Young et al., 1985), and information about specific mycobacterial gene sequences is becoming available (Shinnick, 1987). Such information might prove useful for unequivocally identifying $M$. leprae in isolates of clinical interest or laboratory cultures. We have focussed on rRNA because it is present in several thousand copies in each bacterium and hence probes directed towards rRNA should have a much greater sensitivity than probes directed towards genomic sequences.

We now report the isolation of RNA from $M$. leprae recovered from infected armadillo tissue, and the identification of the nucleotide sequence near to the $3^{\prime}$ end of $16 \mathrm{~S}$ rRNA by the method of primer extension (Lane et al., 1985).

\section{METHODS}

Materials. The following items were purchased from the sources indicated: lysozyme, lipase, dithiothreitol (DTT), TEMED, xylene cyanol FF, 2-mercaptoethanol, Tris, EDTA and boric acid from Sigma; Tween 80 from Bio-Rad; ammonium persulphate, glacial acetic acid, methanol, Aristar guanidinium chloride, bromophenol blue and formamide from BDH; AMV reverse transcriptase (FPLC pure), Sephadex G-50, Sephadex G-200, and deoxy- and dideoxyribonucleotide triphosphates from Pharmacia; T4 polynucleotide kinase and oligodeoxyribonucleotides from Anglian Biotechnology; deoxyadenosine $5^{\prime}-\alpha\left[{ }^{35}\right.$ S $]$ thiotriphosphate $\left(\left[\alpha-{ }^{35} S\right] \mathrm{dATP} ; 600 \mathrm{Ci}\right.$ $\left.\mathrm{mmol}^{-1}, 22 \cdot 2 \mathrm{TBq} \mathrm{mmol}^{-1}\right),\left[\gamma^{-32} \mathrm{P}\right] \mathrm{ATP}\left(3000 \mathrm{Ci} \mathrm{mmol}^{-1}, 111 \mathrm{TBq} \mathrm{mmol}^{-1}\right)$ and placental RNAase inhibitor from Amersham; X-ray film from Kodak and Fuji.

Media for bacterial cultures. LB medium $\left(1^{-1}\right)$ : Bactotryptone $(10 \mathrm{~g})$, Bacto-yeast extract $(5 \mathrm{~g}), \mathrm{NaCl}(10 \mathrm{~g})$, adjusted to $\mathrm{pH} 7 \cdot 5$. YEME medium $\left(1^{-1}\right)$ : Difco yeast extract $(3 \mathrm{~g})$, Difco bactopeptone $(5 \mathrm{~g})$, Oxoid malt extract $(3 \mathrm{~g})$, glucose $(10 \mathrm{~g})$, sucrose $(340 \mathrm{~g}), 1 \mathrm{M}-\mathrm{MgCl}_{2}(5 \mathrm{ml})$. Nutrient Tween $\left(1^{-1}\right)$ : Difco nutrient broth $(10 \mathrm{~g})$, Tween

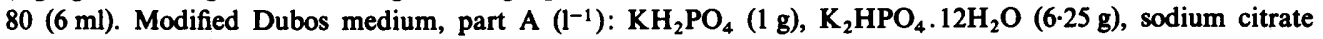
$(1.25 \mathrm{~g}), \mathrm{MgSO}_{4} .7 \mathrm{H}_{2} \mathrm{O}(0.6 \mathrm{~g})$, asparagine $(2 \mathrm{~g}), 10 \%(\mathrm{v} / \mathrm{v}) \mathrm{Tween} 80(5 \mathrm{ml}), 20 \%(\mathrm{w} / \mathrm{v})$ Casamino acids $(10 \mathrm{ml})$, adjusted to $\mathrm{pH} 7 \cdot 2$. Modified Dubos medium, part $\mathrm{B}\left(\mathrm{l}^{-1}\right): 10 \%(\mathrm{w} / \mathrm{v})$ bovine serum albumin fraction $\mathrm{V}$. Immediately before use, $4 \mathrm{ml}$ part $B$ is mixed with $100 \mathrm{ml}$ part $\mathrm{A}$. Tween/glutamate medium, part A (in 0.9 l): sodium glutamate $(8 \mathrm{~g})$, Bactocasitone $(1 \mathrm{~g}), \mathrm{KH}_{2} \mathrm{PO}_{4}(1 \mathrm{~g}), \mathrm{Na}_{2} \mathrm{HPO}_{4}(2.5 \mathrm{~g})$, Tween $80(0.5 \mathrm{ml}), \mathrm{CaCl}_{2} .2 \mathrm{H}_{2} \mathrm{O}$ $(1 \mathrm{mg}), \mathrm{CuSO}_{4} .5 \mathrm{H}_{2} \mathrm{O}(0.5 \mathrm{mg}), \mathrm{ZnSO}_{4} .7 \mathrm{H}_{2} \mathrm{O}(0.5 \mathrm{mg})$. Tween/glutamate medium, part $\mathrm{B}$ (in 0.1 1): bovine serum albumin $(5 \mathrm{~g})$, ferric ammonium citrate $(0.1 \mathrm{~g})$. Immediately before use, $900 \mathrm{ml}$ part $A$ is mixed with $100 \mathrm{ml}$ part $\mathrm{B}$.

Culture of bacteria. Escherichia coli (Y1090) was grown in LB medium at $37^{\circ} \mathrm{C}$ overnight on a rotary shaker. Streptomyces lividans (TK64) was grown in YEME medium at $30^{\circ} \mathrm{C}$ for $48 \mathrm{~h}$ on a rotary shaker. Mycobacterium 
smegmatis (ATCC 607) and Mycobacterium vaccae (given by Dr J. L. Stanford, Middlesex Hospital Medical School, London) were grown in nutrient Tween medium at $37^{\circ} \mathrm{C}$ for $3 \mathrm{~d}$ on a rotary shaker. Mycobacterium tuberculosis $\left(\mathrm{H}_{37} \mathrm{Rv}\right)$ was grown in modified Dubos medium at $37^{\circ} \mathrm{C}$ : glycine was added in exponential phase to a concentration of $0.2 \mathrm{M}$ and incubation was continued for $48 \mathrm{~h}$. Mycobacterium microti (OV254) was grown in Tween/glutamate medium at $37^{\circ} \mathrm{C}$. M. leprae was isolated from the skin nodules of a Nine-banded Armadillo according to the most recent IMMLEP procedure (World Health Organization, 1980).

Isolation of RNA. Cultures of $E$. coli, S. lividans, $M$. smegmatis, $M$. vaccae and $M$. microti were harvested by centrifugation, resuspended in lysis buffer $(6 \mathrm{M}$-guanidinium chloride, $0 \cdot 1 \%, \mathrm{v} / \mathrm{v}$, Tween $80,1 \mathrm{mM}-2$ mercaptoethanol, 10 mM-EDTA, pH 7.0) and passed through a French pressure cell (Aminco) at $18000 \mathrm{lbf}^{-2}$ at $-10^{\circ} \mathrm{C}$. Insoluble debris was removed by centrifugation at $5000 \mathrm{~g}$ for $10 \mathrm{~min}$ and the supernatant was deproteinized by repeated extraction with chloroform/octanol $(24: 1, \mathrm{v} / \mathrm{v})$. RNA was precipitated by the dropwise addition of a 0.5 volume of ethanol (Cox, 1968; Katoch \& Cox, 1986).

$M$. tuberculosis cultures were harvested and resuspended in $10 \mathrm{mM}-\mathrm{Tris} / \mathrm{HCl}(\mathrm{pH} 8.0), 1 \mathrm{mM}-\mathrm{EDTA}, 0 \cdot 1 \%(\mathrm{v} / \mathrm{v})$ Tween 80 containing lysozyme and lipase $\left(2 \mathrm{mg} \mathrm{ml}^{-1}\right.$ each) and shaken at $37^{\circ} \mathrm{C}$ for $2 \mathrm{~h}$. Cells were pelleted and resuspended in lysis buffer containing $0 \cdot 1 \%(\mathrm{v} / \mathrm{v})$ Triton X-100 and shaken at room temperature for $15 \mathrm{~min}$ to induce lysis. Cell debris was removed and RNA was precipitated as above.

$M$. leprae $\left(3 \times 10^{10}\right.$ cells) was treated with lysozyme and lipase as above, resuspended in lysis buffer and passed through a French pressure cell at $18000 \mathrm{lbf}^{-2}$ three times. Debris was removed and RNA was precipitated as above.

$5^{\prime}$ End labelling of oligonucleotide primer. The reaction mixture contained 75 pmol primer, $150 \mu \mathrm{Ci}\left[\gamma^{-32} \mathrm{P}\right] \mathrm{ATP}$ and 30 units of polynucleotide kinase in $50 \mu \mathrm{l} 50 \mathrm{~mm}-\mathrm{Tris} / \mathrm{HCl}(\mathrm{pH} 7 \cdot 6), 10 \mathrm{~mm}-\mathrm{MgCl}_{2}, 5 \mathrm{~mm}-\mathrm{DTT}, 0 \cdot 1 \mathrm{mM}-$ spermidine. After incubation at $37^{\circ} \mathrm{C}$ for $30 \mathrm{~min}, 2 \mu \mathrm{l} 0.5 \mathrm{M}$-EDTA was added and the reaction was heated to $70^{\circ} \mathrm{C}$ for $10 \mathrm{~min}$. Labelled primer was recovered by gel filtration on Sephadex G-50.

Hybridization of primer to RNA. The reaction mixtures contained $0.3 \mathrm{pmol}{ }^{32} \mathrm{P}$-labelled primer and $20 \mu \mathrm{g}$ RA in $10 \mu \mathrm{l} 50 \mathrm{mM}$-Tris/ $\mathrm{HCl}$ ( $\mathrm{pH} \mathrm{8.0)}, 6 \mathrm{mM}-\mathrm{MgCl}_{2}, 40 \mathrm{mM}-\mathrm{KCl}$ (annealing buffer), and was incubated at $70^{\circ} \mathrm{C}$ for $10 \mathrm{~min}$ and cooled on ice. The 16S rRNA.primer complex was isolated by gel filtration on Sephadex G-200 (Amicon-Wright column, $0.8 \mathrm{~cm}$ diameter $\times 5 \mathrm{~cm}$ ) run in $10 \mathrm{mM}$-Tris $/ \mathrm{HCl}(\mathrm{pH} 8.0), 200 \mathrm{mM}-\mathrm{NaCl}, 6 \mathrm{mM}-\mathrm{MgCl}_{2}$, $1 \mathrm{mM}$-EDTA at $35^{\circ} \mathrm{C}$.

The equilibrium constant $(K)$ for the association of primer I with $16 \mathrm{~S}$ rRNA was calculated for the reaction given in equation 1 by equation 2 .

$$
\begin{aligned}
& \text { rRNA }+ \text { primer } \rightleftharpoons \text { rRNA.primer } \\
& K=\frac{x p^{0}}{(1-x) p^{0}\left(r^{0}-x p^{0}\right)} \approx \frac{x}{(1-x) r^{0}}
\end{aligned}
$$

$r^{0}$ and $p^{0}$ are the initial concentrations, respectively, of RNA and primer; $x$ is the fraction of primer bound to $16 \mathrm{~S}$ rRNA at equilibrium. When ${ }^{32}$ P-labelled primer was used $r^{0} \gg x p^{0}$, so that $r^{0}-x p^{0} \approx r^{0}$. On gel filtration the primer bound to 16S rRNA $\left(x p^{0}\right)$ is detected in the void volume, whereas the non-bound primer [ $\left.(1-x) p^{0}\right]$ is retarded. Hence $K$ may be evaluated by measuring the radioactivity (c.p.m.) of the void volume and of the fractions retarded by the column (see equation 3 ).

$$
K \approx \frac{\text { c.p.m. (void volume) }}{\text { c.p.m. (retarded) } r^{0}}
$$

The concentration of RNA was measured by spectrophotometry by means of the relation that an absorbance of 1.0 at $260 \mathrm{~nm}$ is equivalent to $40 \mu \mathrm{g}$ RNA ml-1 [i.e. $\varepsilon 7750 \mathrm{l}^{-1}\left(\mathrm{~mol} \mathrm{PO}_{4}^{-2}\right)^{-1} \mathrm{~cm}^{-1}$ ] and that $16 \mathrm{~S}$ rRA is approximately one-third of the total RNA assuming that $16 \mathrm{~S}$ and $23 \mathrm{~S}$ rRNA are present in equimolar amounts and the ratio of $M_{\mathrm{r}}$ values is $1: 2$.

RNA sequencing. This was done by the dideoxynucleotide termination method of Sanger et al. (1977) modified for the use of reverse transcriptase and RNA templates by Lane et al. (1985). RNA ( $7 \mu \mathrm{g})$ was mixed with $0 \cdot 15 \mu \mathrm{g}$ primer in $7.5 \mu 150 \mathrm{mM}$-Tris/ $\mathrm{HCl}(\mathrm{pH} 8.3), 50 \mathrm{mM}-\mathrm{KCl}$, and $30 \mu \mathrm{Ci}$ dried [ $\left.{ }^{35} \mathrm{~S}\right] \mathrm{dATP}$ was dissolved in $6.5 \mu 1$ of this mix. To this were added $6.5 \mu \mathrm{l} 250 \mathrm{mM}-\mathrm{Tris} / \mathrm{HCl}$ (pH 8.3), $250 \mathrm{mM}-\mathrm{KCl}, 50 \mathrm{mM}-\mathrm{DTT}, 50 \mathrm{mM}-\mathrm{MgCl}_{2}$, and $6.5 \mu \mathrm{l}$ reverse transcriptase diluted to 1 unit $\mu \mathrm{l}^{-1}$ in $50 \mathrm{~mm}-\mathrm{Tris} / \mathrm{HCl}(\mathrm{pH} 8.3), 2 \mathrm{~mm}-\mathrm{DTT}, 50 \%$ (v/v) glycerol. Portions $(3 \mu \mathrm{l})$ were dispensed to each of five tubes, and $2 \mu 1$ of nucleotide mix $(250 \mu \mathrm{M}$ each of dTTP, dCTP and dGTP in $10 \mathrm{mM}$-Tris/HCl, pH 8.3) lacking or containing one of the dideoxynucleotides (1.25 $\mu \mathrm{M}$-ddATP, $30 \mu \mathrm{M}$-ddTTP, $30 \mu \mathrm{M}$-ddCTP or $19 \mu \mathrm{M}$-ddGTP) were added. The reactions were incubated at room temperature for $5 \mathrm{~min}$, and then at $37^{\circ} \mathrm{C}$ for $30 \mathrm{~min} ; 1 \mu \mathrm{l}$ of chase mix (all four dNTPs at $1 \mathrm{mM}$ ) was added and incubation was continued for a further $15 \mathrm{~min}$. Reactions were cooled on ice and $6 \mu \mathrm{lof}$ stop mix $(90 \%, \mathrm{v} / \mathrm{v}$, deionized formamide, $10 \mathrm{mM}-\mathrm{EDTA}$,

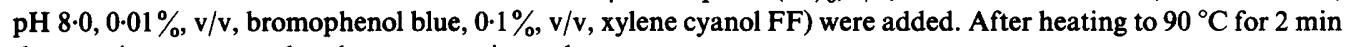
the reactions were analysed on sequencing gels.

Sequencing gels. These were $0.3 \mathrm{~mm}$ thick and $38 \mathrm{~cm}$ long (Sanger \& Coulson, 1978); they consisted of $6 \%$ (w/v) 
acrylamide and $0.3 \%(\mathrm{w} / \mathrm{v})$ bisacrylamide in TBE buffer ( $89 \mathrm{~mm}$-Tris base, $89 \mathrm{~mm}$-boric acid, $20 \mathrm{~mm}$-EDTA), polymerized by the addition of $40 \mu \mathrm{l}$ TEMED and $25 \mu 125 \%(\mathrm{w} / \mathrm{v})$ ammonium persulphate per $50 \mathrm{ml}$. Electrophoresis was done at $1500 \mathrm{~V}$ for $1-4 \mathrm{~h}$ in TBE buffer. Gels were fixed in $10 \%(\mathrm{w} / \mathrm{v})$ acetic acid for $10 \mathrm{~min}$ at room temperature prior to exposure to X-ray film.

Formamide-agarose gel electrophoresis. The molecular size distribution of RNA samples was analysed on $1 \%$ $(\mathrm{w} / \mathrm{v})$ agarose gels in $50 \%(\mathrm{v} / \mathrm{v})$ deionized formamide, $0.1 \times \mathrm{E}$ buffer $\left(3.6 \mathrm{mM}-\mathrm{Tris}\right.$ base, $3.0 \mathrm{mM}-\mathrm{Na}_{2} \mathrm{HPO}_{4}$, 0.2 mM-EDTA). Samples were made up to $50 \%$ formamide, $0.1 \times \mathrm{E}$ buffer, $5 \%$ glycerol and $0.05 \%$ bromophenol blue and heated to $60^{\circ} \mathrm{C}$ for $3 \mathrm{~min}$ prior to running at $100 \mathrm{~V}(25 \mathrm{~mA})$ for $2 \mathrm{~h}$. E. coli rRNA was used as a standard.

\section{RESULTS AND DISCUSSION}

RNA isolated from armadillo-grown $M$. leprae was found to consist of two principal components, which co-migrate with the 16S and 23S rRNAs of E. coli. M. tuberculosis (Worcel et al., 1968) and Mycobacterium bovis (Suzuki et al., 1987) have also been shown to contain rRNAs of these sizes. The yield of rRNA ( $175 \mu \mathrm{g}$ from $3 \times 10^{10} \mathrm{M}$. leprae), allowing for a $50 \%$ loss during the isolation and purification procedure, suggests that there are approximately 4000 ribosomes per mycobacterium, compared with approximately 20000 ribosomes per bacterium found by Tissières et al. (1959) in stationary phase $E$. coli. However, since $M$. leprae harvested from infected tissue is known to include a large proportion of non-viable bacilli, the number of ribosomes per viable bacillus could be much higher than this figure.

Oligonucleotide primers were designed to hybridize with regions of the 16S rRNA sequence which are highly conserved among prokaryotes. The total RNA fraction was used without further purification for the determination of nucleotide sequence by primer extension using reverse transcriptase (Lane et al., 1985). Conditions for binding oligodeoxyribonucleotide primers to mycobacterial rRNA were investigated using ${ }^{32} \mathrm{P}$-labelled primer I (5'AAGGAGGTGATCCA(T/C)CCGC3'), which is complementary to residues 1522-1541 of E. coli (Noller, 1984). The $K$ values of this primer for $16 \mathrm{~S}$ rRNAs from three cultivatable mycobacteria were compared with those for $E$. coli and $S$. lividans. The results are summarized in Table 1, which shows that the stability of the $16 \mathrm{~S}$ rRNA. primer I complex was similar in all five species. However, using this primer, no significant cDNA synthesis was obtained with reverse transcriptase using RNAs from $E$. coli, $M$. leprae or other mycobacterial species. The enzyme is known to stop at methylated adenine (Hagenbuchle et al., 1978), and guanine residues (Youvan $\&$ Hearst, 1981); in $E$. coli there are two methylated adenine residues immediately upstream from the primer binding site (bases 1518, 1519; Brosius et al., 1978). We infer that mycobacterial $16 \mathrm{~S}$ rRNA has a sequence complementary to primer I (with none or very few mismatches) and that there is similar methylation of nucleotides in this region.

When primer II (5'TACGGCTACCTTGTTACGACTT3') was used (see Fig. 1), the sequence of 277 nucleotides was established from residues 1230-1507, using the numbering system for $E$. coli. The $16 \mathrm{~S}$ rRNA sequences that are conserved between $M$. leprae and nine archaebacteria, 13 eubacteria and four chloroplast species (Huysmans \& De Wachter, 1986) are boxed in Fig. 1. The changes in sequence as compared to $E$. coli result in conservation of the

Table 1. Equilibrium constant $(K)$ for the complex formed between $16 S$ rRNA and ${ }^{32}$ P-labelled primer-I

$\begin{array}{lc}\text { rRNA species } & \begin{array}{c}10^{5} \times K \\ \left(1 \mathrm{~mol}^{-1}\right)^{*}\end{array} \\ \text { E. coli } & 1.18 \\ \text { S. lividans } & 1.26 \\ \text { M. smegmatis } & 0.87 \\ M \text {. vaccae } & 0.73 \\ M . \text { microti } & 0.87\end{array}$

\footnotetext{
* $K$ was measured by gel filtration (Sephadex-G200) as described in Methods. The concentration is expressed as mol nucleotide $1^{-1}$.
} 


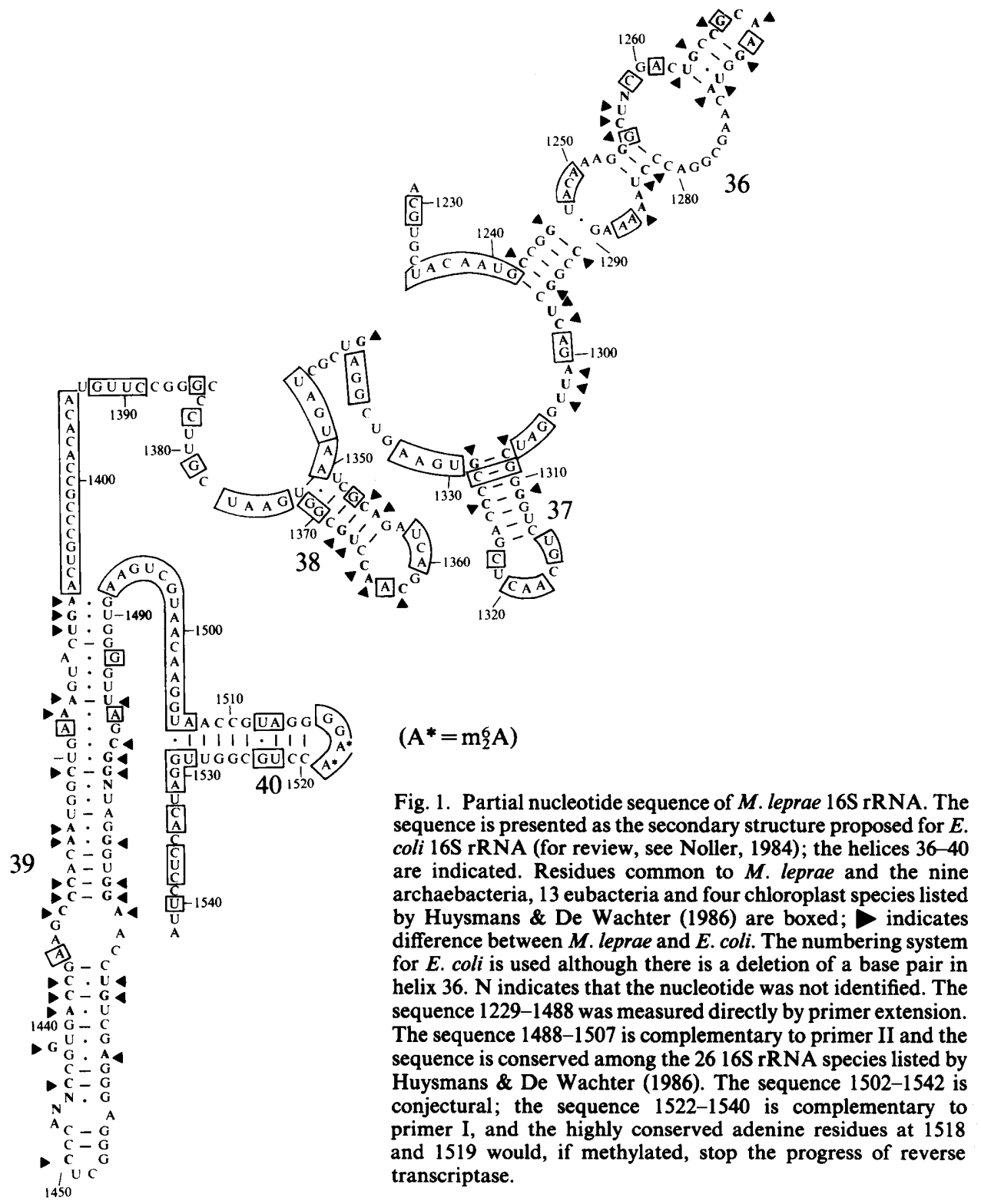

secondary structure proposed for $E$. coli (Noller, 1984), suggesting that this scheme is also applicable to $M$. leprae.

These highly conserved residues account for 97 of the nucleotides sequenced. Of the remaining 180 bases the $M$. leprae sequence has a higher proportion of $\mathrm{GC}$ base pairs than the $E$. coli sequence, which is consistent with the known high $\mathrm{G}+\mathrm{C}$ content of mycobacterial DNA (55.8\% for $M$. leprae, Imaeda et al., 1982), and differs from the $E$. coli sequence at 62 sites. There are fewer (41) differences between $M$. leprae (Fig. 1) and $S$. lividans (Bibb \& Cohen, 1982) sequences, suggesting that $M$. leprae is more closely related to the latter than to $E$. coli.

The sequence data of $M$. leprae 16S rRNA may be extended by the use of other suitable oligodeoxyribonucleotide primers based on rRNA sequences which are widely conserved among prokaryotes. The methods described above are generally applicable, and are suitable for 
the study of other mycobacteria. The observation that there are probably several thousand rRNA copies per $M$. leprae bacillus, and that the $M$. leprae 16S rRNA sequence shows differences from other prokaryotic 16S rRNA sequences suggests that it should be possible to design specific oligonucleotide probes capable of detecting $M$. leprae in infected tissue.

This investigation received financial support from the UNDP/World Bank/WHO Special Programme for Research and Training in Tropical Diseases. I.C.E. E.-G. was funded by the British Leprosy Relief Association (LEPRA) and the British Council.

\section{REFERENCES}

BIBB, M. J. \& COHEN, S. N. (1982). Gene expression in Streptomyces: construction and application of promoter-probe plasmid vectors in Streptomyces lividans. Molecular and General Genetics 187, 265-277.

Brosius, J., Palmer, M. L., Kennedy, P. J. \& Noller, H. F. (1978). Complete nucleotide sequence of a $16 \mathrm{~S}$ ribosomal RNA gene from Escherichia coli. Proceedings of the National Academy of Sciences of the United States of America 75, 48014805.

Clark-Curtiss, J. E., JaCobs, W. R., Docherty, M. A., RITCHIE, L. R. \& CURTISS, R., III (1985). Molecular analysis of DNA and construction of genomic libraries of Mycobacterium leprae. Journal of Bacteriology 161, 1093-1102.

Cox, R. A. (1968). The use of guanidinium chloride in the isolation of nucleic acids. Methods in Enzymology 12B, 120-129.

Hagenbuchle, O., SANTer, M., Steitz, J. A. \& Mans, R. J. (1978). Conservation of the primary structure at the 3 'end of $18 S$ rRNA from eukaryotic cells. Cell 13, 551-563.

HuYsmans \& De Wachter, R. (1986). Compilation of small subunit RNA sequences. Nucleic Acids Research 14, r73-r118.

IMAEDA, T., KIRCHHEIMER, W. F. \& BARKSDALE, L. (1982). DNA isolated from Mycobacterium leprae: genome size, base ratio, and homology with other related bacteria as determined by optical DNADNA reassociation. Journal of Bacteriology 150, 414 417.

KATOCH, V. M. \& CoX, R. A. (1986). Stepwise isolation of RNA and DNA from mycobacteria. International Journal of Leprosy 54, 409-415.

Lane, D. J., Pace, B., Olsen, G. J., Stahl, D. A., SOGIN, M. L. \& PACE, N. R. (1985). Rapid determination of 16S ribosomal RNA sequences for phylogenetic analyses. Proceedings of the National Academy of Sciences of the United States of America 82, 6955-6959.

Noller, H. (1984). Structure of ribosomal RNA. Annual Review of Biochemistry 53, 119-231.
SANGer, F., Nicklen, S. \& Coulson, A. R. (1977). DNA sequencing with chain-terminating inhibitors. Proceedings of the National Academy of Sciences of the United States of America 74, 5463-5467.

SANGER, F. \& Coulson, A. R. (1978). The use of thin acrylamide gels for DNA sequencing. FEBS Letters 87, $107-110$.

SHINNICK, T. M. (1987). The 65-kilodalton antigen of Mycobacterium tuberculosis. Journal of Bacteriology 169, 1080-1088.

Suzuki, Y., Yoshinaga, K., Ono, Y., Nagata, A. \& YAMADA, T. (1987). Organisation of rRNA genes in Mycobacterium bovis BCG. Journal of Bacteriology 169, 839-843.

Tissières, A., Watson, J. D., Schlessinger, D. \& HOLLINGWORTH, B. R. (1959). Ribonucleoprotein particles from Escherichia coli. Journal of Molecular Biology 1, 221-233.

Worcel, A., Goldman, D. S. \& SACHS, I. B. (1968). Properties and fine structure of the ribosomes from Mycobacterium tuberculosis. Proceedings of the National Academy of Sciences of the United States of America 61, 122-129.

World Health ORganization (1980). UNDP/World Bank/WHO Special Programme for Research and Training in Tropical Diseases. Report of the Fifth Meeting of the Scientific Working Group on the Immunology of Leprosy (IMMLEP). TDR/IMMLEP-SWG(5)/80.3, Annex 4, p. 23. Geneva: World Health Organization.

Young, R. A., Mehra, V., SweEtser, D., Buchanan, T., Clark-Curtiss, J., Davis, R. W. \& Bloom, B. R. (1985). Genes for the major protein antigens of the leprosy parasite Mycobacterium leprae. Nature, London 316, 450-452.

Youvan, D. C. \& Hearst, J. E. (1981). A sequence from Drosophila melanogaster $18 \mathrm{~S}$ rRNA bearing the conserved hypermodified nucleoside am $\psi$ : analysis by reverse transcription and high-performance liquid chromatography. Nucleic Acids Research 9, 17231741 . 